\title{
Contribution of streambanks to phosphorus export from lowa
}

\author{
K.E. Schilling, T.M. Isenhart, C.F. Wolter, M.T. Streeter, and J.L. Kovar
}

\begin{abstract}
Phosphorus (P) from nonpoint upland and channel sources contributes to development of hypoxic conditions in receiving waters around the world. Streambanks are thought to be a potentially large contributor to sediment $\mathrm{P}$ loads in agricultural watersheds, but are often unaccounted for in $\mathrm{P}$ loss reduction strategies. In this analysis, we estimate the contribution of streambank sources to total $\mathrm{P}(\mathrm{TP})$ export from the state of Iowa using a multistep process and relate this to overall statewide P export. Using GIS mapping and field monitoring, we estimate that $35,200 \mathrm{~m}$ of $3.2 \mathrm{~m}$ high streambanks are actively eroding in Iowa rivers at a rate of $12.4 \mathrm{~cm} \mathrm{y}^{-1}$. With an average streambank soil TP concentration of $470 \mathrm{mg} \mathrm{kg}^{-1}$ and bulk density of $1.17 \mathrm{~g} \mathrm{~cm}^{-3}$, approximately $7,681 \mathrm{Mg}$ of TP is annually eroded from streambanks and delivered to Iowa rivers. Over an 18 -year period, we estimate that streambanks contributed approximately $31 \%$ of the riverine TP export from Iowa. Despite limitations in our analysis, an improved understanding of streambank $\mathrm{P}$ contributions will help natural resource managers make appropriate recommendations for effective soil and water conservation practices that best reduce $\mathrm{P}$ loading to rivers. Our study is believed to be among the first to address the issue of streambank $\mathrm{P}$ at a scale that has confounded many state and regional nutrient assessments.
\end{abstract}

Key words: erosion—nonpoint source pollution—phosphorus—streambank

\begin{abstract}
Riverine nutrients, consisting principally of nitrogen ( $\mathrm{N}$; predominantly in the form of $\mathrm{NO}-\mathrm{N}$ ) and phosphorus (P) are major contributors to development of hypoxic conditions in the Gulf of Mexico (Turner et al. 2008) and estuaries and lakes around the world (Diaz 2001). Although $\mathrm{N}$ has received more attention (Jones et al. 2018), P export has been viewed by some researchers as a potential limiting nutrient in phytoplankton growth in many freshwater ecosystems and coastal waters (USEPA 2007; Sylvan et al. 2006; Hecky and Kilham 1988). Watershed sources of total P (TP; sum of particulate and dissolved $\mathrm{P}$ ) to river systems can vary, but nonpoint sources such as soil erosion, farm fertilizers, and manure, along with point source discharge of urban wastewater, are thought to comprise the largest TP contributions (Jacobson et al. 2011; Robertson and Saad 2013).

Transport of TP to rivers occurs via highly episodic, event-driven transport or through
\end{abstract} al. (2020) reported much greater export of particulate $\mathrm{P}$ in vulnerable regions where intense agricultural production is occurring on poorly drained and sloping soils.

Although streambank erosion is a natural geomorphic and ecologic process (Piegay et al. 2005; Florsheim et al. 2008), it is being increasingly recognized that excessive streambank erosion can be a potentially large contributor to sediment loads in agricultural watersheds (Simon et al. 2000; Sekely et al.
2002; Wilson et al. 2008; Miller et al. 2014; Palmer et al. 2014; Fox et al. 2016). Shifts in stream equilibrium due to land use change (agriculture, urbanization), drainage, channelization, dams, and other changes can alter the balance between erosion and deposition in a river system and increase channel instability (Simon and Rinaldi 2000). Streambank contributions to annual sediment loads tend to be highly variable and episodic, with annual contributions ranging from $<10 \%$ to $96 \%$ (Wilkin et al. 1982; Hamlett et al. 1983; Thoma et al. 2005; Wilson et al. 2008; Schilling et al. 2011; Belmont et al. 2011; Willett et al. 2012). Palmer et al. (2014) reported that in Iowa, annual streambank contributions ranged from $0 \%$ to $2 \%$ during dry years and up to $53 \%$ during a wet year over a seven-year monitoring period. Streambank erosion can also be a major source of watershed-scale TP export (Fox et al. 2016) with estimates ranging from $15 \%$ to $93 \%$ in Denmark (Laubel et al. 2003; Kronvang et al. 1997), $7 \%$ to $10 \%$ in Minnesota (Sekely et al. 2002), 31\% to 100\% in Oklahoma (Miller et al. 2014; Purvis et al. 2016), 6\% to 30\% in Vermont (Ishee et al. 2015), and $3 \%$ to $38 \%$ in Iowa (Beck et al. 2018).

In Iowa, as in other US Midwestern states, efforts are underway to reduce nutrient loading through implementation of various nutrient reduction strategies (INRS 2014; Christianson 2018). Notably absent from many of these strategies is an estimate of the load contribution from streambanks due to the paucity of bank recession data and when available, its high temporal and spatial variability (Beck et al. 2018). The Iowa Nutrient Reduction Strategy (INRS) specifically stated that the statewide P load evaluation did not include streambank sources despite the fact that streambanks were known to be a potentially large source of stream sediment.

Received March 3, 2021; Revised June 28, 2021; Accepted July 11, 2021.

Keith E. Schilling is state geologist and director of the lowa Geological Survey at the University of lowa, lowa City, lowa. Thomas M. Isenhart is professor in the Department of Natural Resource Ecology and Management at lowa State University, Ames, lowa. Calvin F. Wolter is a GIS specialist at the lowa Department of Natural Resources, Des Moines, lowa. Matthew T. Streeter is a soil scientist at the lowa Geological Survey at the University of lowa, lowa City, lowa. John L. Kovar is a research scientist at USDA National Laboratory for Agriculture and Environment, Ames, lowa. 
Previous work in Iowa quantifying streambank sources of TP has mainly focused on small watersheds in southern Iowa (Walnut Creek [Beck et al. 2018]; Rathbun Lake [Tufekcioglu et al. 2012]) and north central Iowa (Onion Creek [Williams 2019]). We are not aware of other efforts to quantify the contribution of streambank sources of $\mathrm{P}$ to export loads at larger, regional scales.

In this analysis, we sought to answer the question, "what is the contribution of streambank sources to TP export from the state of Iowa?" We attempted to answer this question by using a multistep process that focused first on quantifying individual elements needed to estimate the locations and rates of streambank erosion in the state, followed by a simple mathematical expression to relate the streambank contributions to overall statewide $\mathrm{P}$ export. We address the limitations of our methodology, and lastly, we highlight the implications of our results for achieving $\mathrm{P}$ reductions in agricultural regions such as the US Corn Belt. Our study follows a systematic approach to be among the first to address this question at a scale that has confounded many state and regional nutrient assessments.

\section{Materials and Methods}

Estimating Statewide Streambank Erosion. We used a simplified equation to identify the key terms required to estimate streambank $\mathrm{P}$ contribution to annual $\mathrm{P}$ export and inform data collection efforts. The mass of $\mathrm{P}$ eroded from streambanks can be estimated by equation 1, which multiplies eroding bank lengths and recession rates by bank heights, bulk density, and soil $\mathrm{P}$ content where

Eroding bank length $(\mathrm{m}) \times$ Bank height $(\mathrm{m})$ $\times$ Recession rate $\left(\mathrm{m} \mathrm{y}^{-1}\right) \times$ Bulk density $(\mathrm{kg}$ $\left.\mathrm{m}^{-3}\right) \times P$ content in streambank soils $\left(\mathrm{mg} \mathrm{kg}^{-1}\right)$ $\times 1 \mathrm{~kg} / 1,000,000 \mathrm{mg}=$ Annual mass of $P$ in eroded streambank soils $\left(\mathrm{kg} \mathrm{y}^{-1}\right)$.

We then quantified annual mass of TP exported from the state of Iowa utilizing $\mathrm{P}$ load estimation modeling that combined ambient water quality monitoring data with streamflow gaging data. Using the total P load estimated with load modeling, we calculated the annual contribution of streambank $\mathrm{P}$ to statewide $\mathrm{P}$ export using equation 2 where

P eroded from streambanks (Mg)/Annual P mass exported from Iowa rivers $(\mathrm{Mg})=$ Fraction of annual $P$ export derived from streambank $P$ sources.

Using this simple accounting framework, we pursued a data collection strategy to provide a first-order approximation of the $\mathrm{P}$ load contributions to annual loads. Our approach was to first summarize data collection efforts and results associated with quantifying the individual terms in equations 1 and 2, followed by the overall estimate of the TP contribution from streambanks to statewide TP export.

Estimating the Extent of Streambank Erosion. A geographic information system (GIS) routine was developed to estimate severe streambank erosion using a $1 \mathrm{~m}$ digital elevation model (DEM) developed from a statewide Light Detection and Ranging (LiDAR) coverage (Wolter et al. 2021). We defined severely eroding streambanks to be consistent with visual assessment criteria developed by the USDA Natural Resources Conservation Service (USDA NRCS 1998). This visual assessment classifies banks that are predominantly bare with overhanging vegetation and exposed roots as severely eroding. Data sources included a $1 \mathrm{~m}$ slope grid, a stream centerline coverage (for wide streams, a stream edge-of-water coverage was used), and a stream order coverage. Field reconnaissance data from intensive streambank mapping campaigns in selected Iowa watersheds were used to develop, calibrate, and validate the DEM-based method to estimate eroding streambank extent.

The methodology is predicated on the assumption that a severe bank angle in adjacent $1 \mathrm{~m}$ DEM cells is indicative of severe streambank erosion. The bank angle between adjacent grid cells is determined by the bank height and grid size ( $z$ dimension; figure 1). Steeper bank angles occur at progressively higher streambank heights, and it was assumed that steep bank angles (slope between adjacent cells) indicate severe streambank erosion. However, since the $x$ distance between adjacent cells is always $1 \mathrm{~m}$, lower bank heights in smaller order streams would have lower bank angles indicative of severe bank erosion. Therefore, field mapping data were used to develop a nomograph table that related bank angles to streambank heights (i.e., slopes between adjacent cells) to select the appropriate bank angle to identify eroding banks (see Wolter et al. [2021] for details of the procedure). To scale this methodology for the entire state, bank heights for all streams in the state were determined using GIS to intersect the state-wide stream centerline and edge-of-water coverages with the streambank heights developed from the $1 \mathrm{~m}$ DEM. Based on the streambank heights and slopes, the extent of severely eroding streambanks in Iowa's third- to sixth-order streams was estimated. Although first- and second-order streams comprise most of the linear kilometers of Iowa's stream network (Schilling and Jacobson 2018), the channel dimensions of these smaller streams are obscured by trees and overhanging vegetation. Thus, bank slopes could not be reliably determined and the methodology could not be applied to these low-order streams.

Mean Streambank Recession Rate. A variety of methods have been used to eval-

\section{Figure 1}

Conceptual diagram of modeling approach to estimate severely eroding streambanks using LiDAR. The drawing shows a cross section of a streambank with the bank angle calculation.

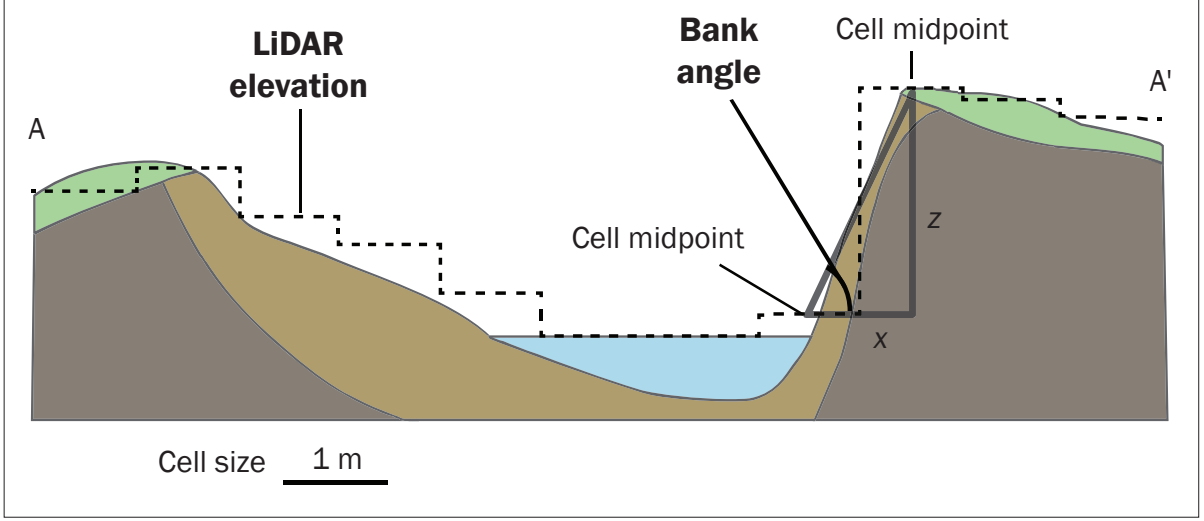


uate rates of streambank recession in Iowa watersheds, including cross-section surveys, bank erosion pin measurements, and photogrammetric methods that include the use of LiDAR systems and sequential aerial photographs (Fox et al. 2016; Tomer and Van Horn 2018; Beck et al. 2019). In low-order Iowa streams, erosion pins have been widely used to measure bank recession at targeted eroding bank segments (Beck et al. 2018; Palmer et al. 2014; Tufekcioglu et al. 2012; Nellesen et al. 2011; Zaimes et al. 2008, 2019).

Since the early 2000s, researchers at Iowa State University have pinned several hundred streambanks across Iowa to measure bank recession in wadable third- to fourth-order channels. At most sites, erosion pins were installed along the bank face in a grid of two rows spaced vertically at one-third and two-thirds bank height and horizontally $1 \mathrm{~m}$ apart along the entire length of the selected eroding bank (figure 2). Erosion pins were typically $762 \mathrm{~mm}$ long and $6.2 \mathrm{~mm}$ in diameter, and exposed lengths of pins were measured using a ruler at least annually. An increase in exposed pin length from the previous measurement was assumed to be from bank recession, whereas a decrease in length was assumed to indicate deposition. For this study, we compiled the annual streambank erosion estimates for 385 streambank-years from five different long-term monitoring sites in the state (table 1). In a separate study, Zaimes et al. (2019) compiled recession rates from nine different Iowa studies that included sites sorted by riparian land cover.

Total Phosphorus Concentrations and Bulk Density of Streambank Soils. Only limited data existed on TP concentrations in Iowa riparian soils and most of these data were watershed specific (Schilling et al. 2009; Nellesen et al. 2011; Beck et al. 2018; Moustakadis et al. 2019), so we conducted a regional, statewide evaluation of streambank soil TP concentrations and bulk density. Major Land Resource Areas (MLRAs) were used as the basis for statewide site selection. Within each of Iowa's eight major MLRAs, eroding banks identified using the eroding bank GIS coverage (Wolter et al. 2021) were selected for sampling based on stream order and public access. In each MLRA, two sites were selected from each stream order (one through six) and one site was selected from stream orders seven and eight when those stream orders were represented within the MLRA (figure 3). The selected streambanks

\section{Figure 2}

Measuring annual streambank recession using erosion pins (photo courtesy of William Beck, lowa State University).

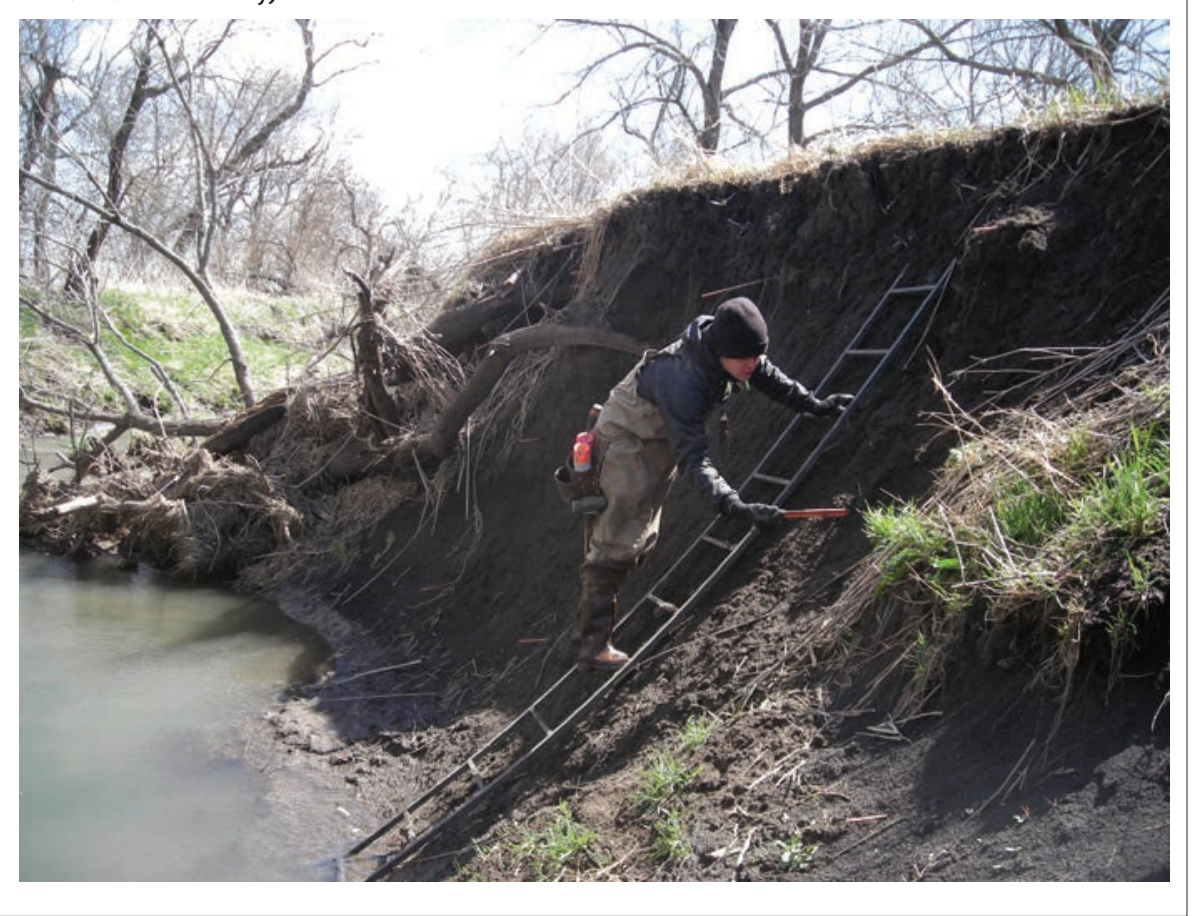

were visually inspected, and samples were collected where banks were bare and unvegetated and considered to be very severely eroding according to visual assessment criteria developed by the NRCS (Schilling and Wolter 1999).

Multiple samples (up to three) were collected from each streambank if alluvial members could be differentiated (representative samples from the Camp Creek, Roberts Creek, and Gunder members of the DeForest Formation) (Schilling et al. 2009). If the units could not be determined, a single mid-bank sample (undifferentiated) was collected. For this statewide assessment, we averaged the individual sample concentrations to calculate a representative $\mathrm{TP}$ value since site-specific variations in TP concentrations were not the focus of this study. Previous work indicated that differences in TP among alluvial stratigraphic units were not statistically significant (Schilling et al. 2009), but future work is planned to examine streambank TP concentration data in more detail. Total $\mathrm{P}$ was determined by digesting the samples in aqua regia (Crosland et al. 1995). Phosphorus concentrations in the digests were determined with the molybdate blue-ascorbic acid colorimetric method of Watanabe and Olsen (1965). Although other $\mathrm{P}$ fractions (e.g., leachable $\mathrm{P}$ ) are important to local water quality and stream processes, these fractions constitute a small percentage of total annual P loss from large watersheds. Total $\mathrm{P}$ fractions in Iowa channel sediments were previously reported by Rahutomo et al. (2018) who found that TP consisted of both inorganic and organic fractions in a southern Iowa stream. At each site, bulk density samples were also collected in duplicate from the same intervals as sampled using a slide hammer and core tube sampler. In total, 148 samples from exposed streambank soils were collected for TP and bulk density analysis.

\section{Results and Discussion}

Estimation of Individual Components. Using model criteria reported in Wolter et al. (2021), we estimated that $35,200 \mathrm{~km}$ of streambanks along third- through sixth-order rivers are severely eroding in Iowa. Total stream length was $42,985 \mathrm{~km}$. Since total stream length was a single linear feature, we doubled this length to account for streambanks on both sides $(85,970 \mathrm{~km}$ of streambanks) and estimated that approximately $41 \%$ of the streambanks in Iowa are severely eroding. More streambank erosion was identified in southwest and southern Iowa than other portions of the state (figure 4), with approximately 35\% to $84 \%$ of all streambanks in these regions estimated to be severely eroding.Across northern 
Table 1

Summary of annual streambank recession rates measured using erosion pins at various lowa sites.

\begin{tabular}{|c|c|c|c|c|c|}
\hline Study & Region of lowa & MLRA & $\begin{array}{l}\text { Years of } \\
\text { monitoring }\end{array}$ & $\begin{array}{l}\text { No. of banks } \\
\text { in study }\end{array}$ & $\begin{array}{l}\text { Recession } \\
\text { rate }\left(\mathrm{cm} \mathrm{y}^{-1}\right)\end{array}$ \\
\hline \multirow[t]{3}{*}{ Beck 2018} & \multirow[t]{3}{*}{ Southern } & \multirow[t]{3}{*}{$108 \mathrm{c}$} & 2016 & 10 & 12.3 \\
\hline & & & 2017 & 10 & 6.3 \\
\hline & & & 2018 & 10 & 18.6 \\
\hline \multirow[t]{7}{*}{ Williams 2019} & \multirow[t]{7}{*}{ Central } & \multirow[t]{7}{*}{103} & 2011 & 28 & -1.23 \\
\hline & & & 2012 & 35 & -0.40 \\
\hline & & & 2013 & 34 & 3.90 \\
\hline & & & 2014 & 35 & 4.63 \\
\hline & & & 2015 & 33 & 21.36 \\
\hline & & & 2017 & 25 & -0.50 \\
\hline & & & 2018 & 24 & 30.97 \\
\hline \multirow{6}{*}{$\begin{array}{l}\text { Palmer } \\
\text { et al. } 2014\end{array}$} & \multirow[t]{6}{*}{ Southern } & \multirow[t]{6}{*}{$108 \mathrm{c}$} & 2005 & 10 & 0.4 \\
\hline & & & 2006 & 10 & -0.6 \\
\hline & & & 2007 to 2008 & 10 & 19.2 \\
\hline & & & 2009 & 10 & 34.2 \\
\hline & & & 2010 & 10 & 27.0 \\
\hline & & & 2011 & 10 & 13.6 \\
\hline \multirow{3}{*}{$\begin{array}{l}\text { Tufekcioglu } \\
\text { et al. } 2012\end{array}$} & \multirow[t]{3}{*}{ Southeast } & \multirow[t]{3}{*}{109} & 2006 & 13 & 11.7 \\
\hline & & & 2007 & 13 & 26.6 \\
\hline & & & 2008 & 13 & 26.3 \\
\hline \multirow{9}{*}{$\begin{array}{l}\text { Zaimes } \\
\text { et al. } 2008\end{array}$} & \multirow[t]{3}{*}{ Central } & \multirow[t]{3}{*}{103} & 2001 & 5 & 10.3 \\
\hline & & & 2002 & 5 & 9.5 \\
\hline & & & 2003 & 5 & 20.2 \\
\hline & \multirow[t]{3}{*}{ Northeast } & \multirow[t]{3}{*}{104} & 2001 & 4 & 5.8 \\
\hline & & & 2002 & 4 & 9.2 \\
\hline & & & 2003 & 4 & 11.9 \\
\hline & \multirow[t]{3}{*}{ Southeast } & \multirow[t]{3}{*}{109} & 2001 & 5 & 8.6 \\
\hline & & & 2002 & 5 & 2.2 \\
\hline & & & 2003 & 5 & 15.1 \\
\hline Average & & & & & 12.4 \\
\hline Standard devia & & & & & 10.3 \\
\hline
\end{tabular}

Note: MLRA = Major Land Resource Area.

Figure 3

Location of streambank soil samples collected from stream order sites located in a range of landscape regions in lowa.

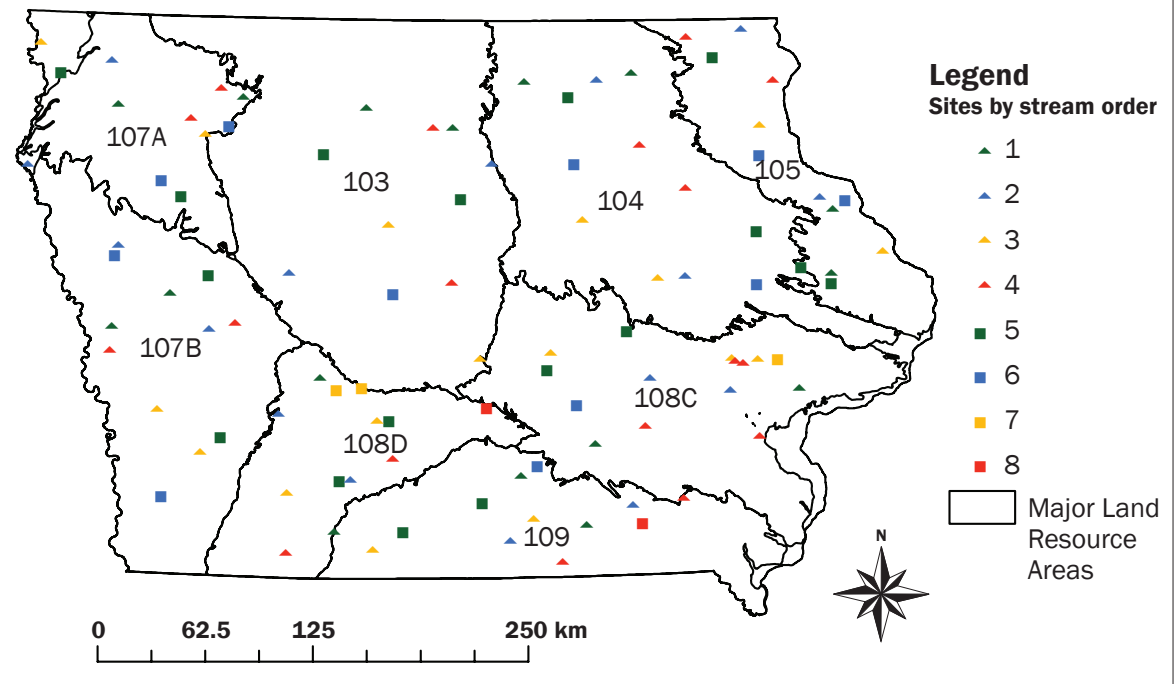

Iowa, the topography is flatter, soils are coarser-textured, and bank heights are lower. The fraction of stream kilometers with severe bank erosion increased with bank height. In southern and southwest Iowa, bank heights exceed $5 \mathrm{~m}$ in larger order streams, but across the state of Iowa, the mean streambank height in third- through sixth-order streams was 3.2 $\mathrm{m}$. From this study, we estimated two terms needed for equation 1, namely the length of eroding streambanks in Iowa $(35,200 \mathrm{~km})$ and mean streambank height $(3.2 \mathrm{~m})$.

Streambank recession rates estimated from published pin studies show wide variability in annual streambank recession rates, ranging from $-1.2 \mathrm{~cm} \mathrm{y}^{-1}$ (deposition) in central Iowa to $34.2 \mathrm{~cm} \mathrm{y}^{-1}$ of bank erosion in a southern Iowa watershed. Among all sites with pin data, an average streambank recession rate for 385 bank years was approximately 12.4 $\pm 10.3 \mathrm{~cm} \mathrm{y}^{-1}$, with a median of $11.0 \mathrm{~cm} \mathrm{y}^{-1}$ (table 1). Since many of the streambank sites were the same, compilation of annual streambank recession rates reported in Zaimes et al. (2019) produced similar results, averaging approximately $12.9 \mathrm{~cm} \mathrm{y}^{-1}$. It is important to note that erosion pins were typically installed in banks identified as severely eroding according to NRCS criteria (USDA NRCS 1998), so the recession rates reflect variations measured in exposed banks and not all channels. Focusing on severely eroding banks links the erosion rates to the GIS mapping of eroding lengths (Wolter et al. 2021) and is consistent with previous studies showing that well-vegetated streambanks do not contribute substantially to streambank erosion rates in a watershed (Schilling and Wolter 2000; Palmer et al. 2014).

Variations in annual recession rates are due to many factors, including riparian land cover (Zaimes et al. 2004, 2006, 2008), cattle grazing (Tufekcioglu et al. 2012), variations in precipitation and discharge (Palmer et al. 2014), and alluvial stratigraphy (Beck et al. 2018). Such factors are consistent with mechanistic processes controlling bank erosion at individual sites around the world (Lawler 1992; Simon and Collison 2002; Pollen et al. 2004; Fox et al. 2007). Some variation in erosion pin data are also due to measurement limitations associated with erosion pins (Hooke 1980; Couper et al. 2002; Palmer et al. 2014). Despite these limitations, for this present study (equation 1), we assumed that recession in severely eroding streambanks in Iowa averaged approximately $12.4 \mathrm{~cm} \mathrm{y}^{-1}$. 


\section{Figure 4}

Location of severely eroding streambank lengths in third- to sixth-order streams and rivers of lowa.

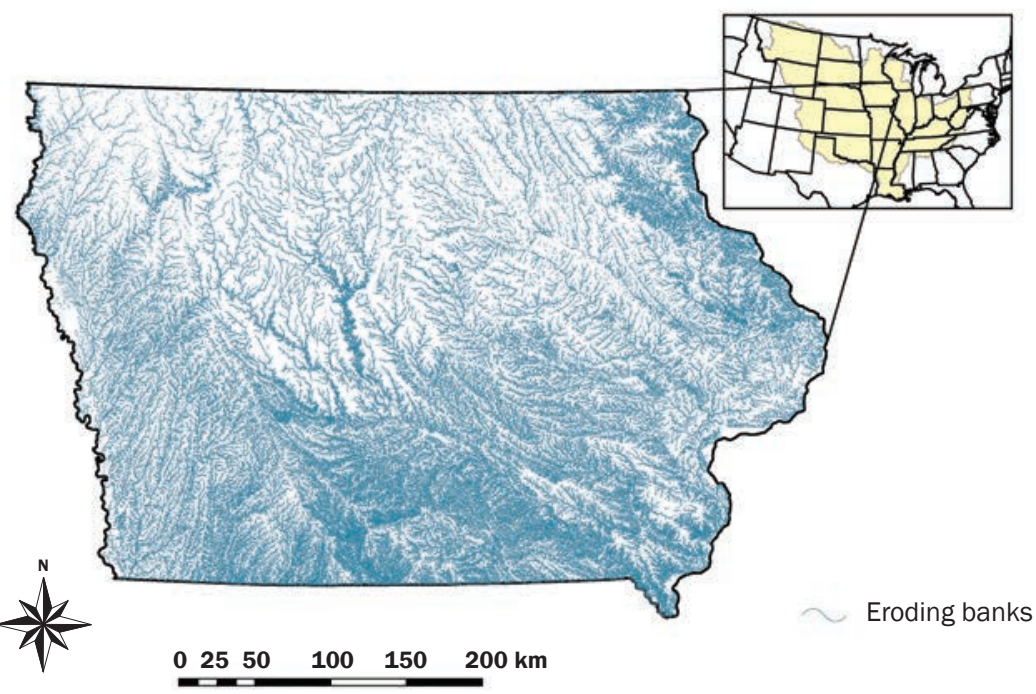

The particle size of the streambank soils was dominated by silt (53\%) with lesser amounts of sand (31\%) and clay (16\%). Among riparian soils, TP concentrations were observed to range from 109 to $1,569 \mathrm{mg} \mathrm{kg}^{-1}$ and average $470 \pm 192 \mathrm{mg} \mathrm{kg}^{-1}$ (figure 5). Although minor differences were observed among various MLRAs or stream order classifications, the variability was mainly associated with an occasional low or high value not represen$1.17 \pm 0.14 \mathrm{~g} \mathrm{~cm}^{-3}$. tative of the entire sample population. Bulk density of exposed streambank soils averaged

What Is the Annual Mass of Phosphorus Eroded from Streambanks? Based on quantification of individual terms, we used equation 1 to estimate the mass of streambank P lost from eroding streambanks. Assuming that $35,200 \mathrm{~m}$ of $3.2 \mathrm{~m}$ high streambanks are actively eroding in Iowa rivers at an annual rate of $12.4 \mathrm{~cm}$

\section{Figure 5}

Frequency distribution of 145 streambank soil total phosphorus (TP) concentrations.

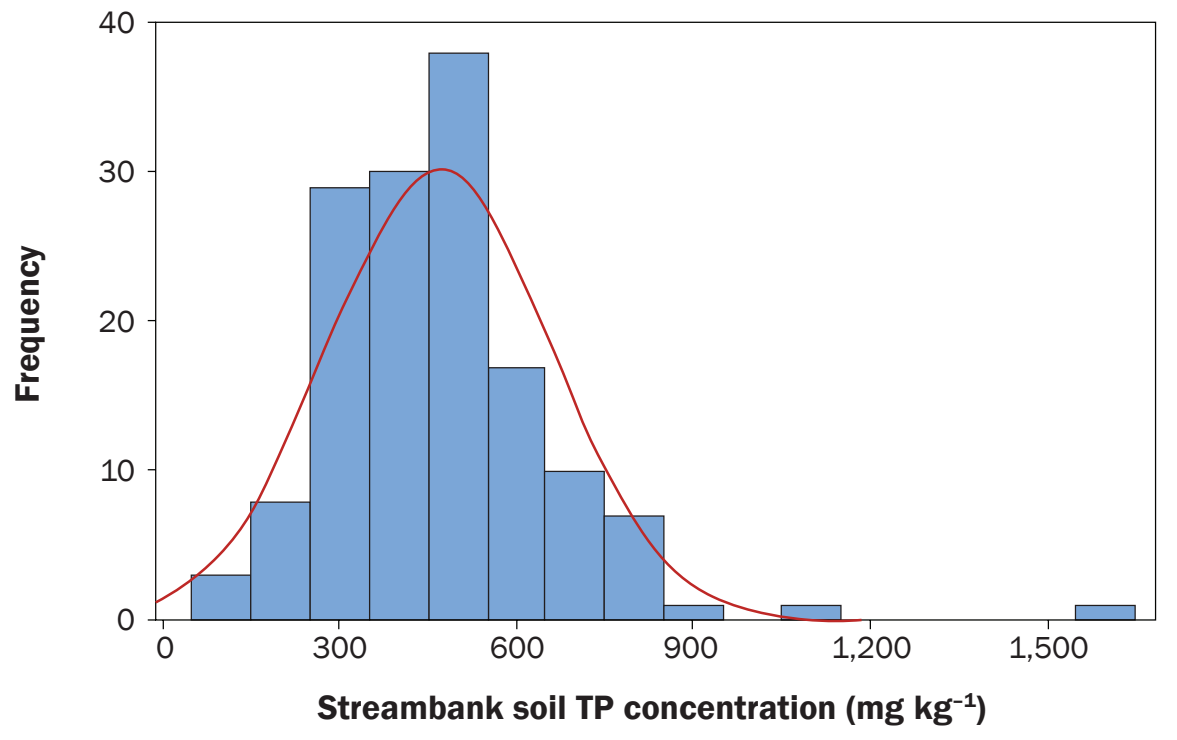

$\mathrm{y}^{-1}$, and a streambank soil TP concentration of $470 \mathrm{mg} \mathrm{kg}^{-1}$ and bulk density $1.17 \mathrm{~g} \mathrm{~cm}^{-3}$, we estimate that approximately $7,681 \mathrm{Mg}$ of TP is eroded from streambanks and annually exported from Iowa.

Since this estimate involved multiple components with their individual sources of variation, we evaluated how variations in the source terms affected the overall estimate of eroded streambank TP (table 2). Since estimates of eroding bank lengths and bank heights were developed from a static DEM and represent a single snapshot in time, we are not able to use measured data to evaluate variations in streambank $P$ estimates. In these cases, we evaluated how variations of $\pm 10 \%$ and $\pm 25 \%$ in eroding lengths and streambank heights impacted the estimated TP mass lost from streambanks. For the streambank recession and TP concentration terms, we considered variations of \pm 1 standard deviation (s.d.) in measured values.

Variation in streambank recession appears to have the greatest effect on estimated TP loss from streambanks (table 2). For example, during dry years when streambank recession is on the order of $2.4 \mathrm{~cm}$, TP loss would be on the order of $1,487 \mathrm{Mg}$, but during a wet year when average recession is $22.4 \mathrm{~cm}$, annual TP loss would be nearly 14,000 Mg. Palmer et al. (2014) reported that recession in some Iowa streambanks exceeded $34 \mathrm{~cm}$ during an exceptionally wet year, and if recession was this high, TP loss from streambanks could exceed 21,000 Mg. On the other hand, variations in TP concentration have less impact than recession rates, with \pm 1 s.d. of concentration yielding estimated TP losses ranging between 4,543 and 10,818 $\mathrm{Mg}$ (table 2).

The lengths of eroding streambanks in watersheds are known to vary over time as eroded streambanks can revegetate in some areas, or in other cases, new bank erosion can emerge (Palmer et al. 2014; Beck et al. 2018). Varying eroding lengths by $\pm 10 \%$ and $\pm 25 \%$ in Iowa rivers did not produce as much variation in TP losses as other parameters (table 2 ). Assuming a change of $\pm 25 \%$ in eroding stream lengths resulted in annual streambank P losses ranging from $5,760 \mathrm{Mg}$ to $9,601 \mathrm{Mg}$.

What Is the Annual Riverine Total Phosphorus Export from Iowa? Estimating the contribution of streambank sources to TP export from the state of Iowa required an estimate of the annual TP export from Iowa rivers (equation 2). Recent work by Schilling et al. (2020) utilized ambient water quality 
Table 2

Variations in estimated annual total phosphorus (TP) export from lowa streambanks using standard assumptions (equation 1) and likely low and high range values of parameters.

\begin{tabular}{|c|c|c|c|c|c|}
\hline Parameter & $\begin{array}{l}\text { Equation } 1 \\
\text { assumption }\end{array}$ & $\begin{array}{l}\text { Low } \\
\text { range }\end{array}$ & $\begin{array}{l}\text { Total } \\
\text { streambank } \\
\text { TP loss (Mg) }\end{array}$ & $\begin{array}{l}\text { High } \\
\text { range }\end{array}$ & $\begin{array}{l}\text { Total } \\
\text { streambank } \\
\text { TP loss (Mg) }\end{array}$ \\
\hline $\begin{array}{l}\text { Streambank } \\
\text { recession ( } \pm 1 \text { s.d.) }\end{array}$ & $12.4 \mathrm{~cm} \mathrm{y}^{-1}$ & $2.4 \mathrm{~cm} \mathrm{y}^{-1}$ & $1,487(6 \%)$ & $22.4 \mathrm{~cm} \mathrm{y}^{-1}$ & $13,875(56 \%)$ \\
\hline $\begin{array}{l}\text { TP concentration } \\
( \pm 1 \text { s.d. })\end{array}$ & $470 \mathrm{mg} \mathrm{kg}^{-1}$ & $278 \mathrm{mg} \mathrm{kg}^{-1}$ & $4,543(18 \%)$ & $662 \mathrm{mg} \mathrm{kg}^{-1}$ & $10,818(44 \%)$ \\
\hline $\begin{array}{l}\text { Eroding lengths } \\
( \pm 10 \%)\end{array}$ & $35,200 \mathrm{~km}$ & 31,680 km & $6,913(28 \%)$ & $38,720 \mathrm{~km}$ & 8,449 (34\%) \\
\hline $\begin{array}{l}\text { Eroding lengths } \\
( \pm 25 \%)\end{array}$ & $35,200 \mathrm{~km}$ & $26,400 \mathrm{~km}$ & $5,760(23 \%)$ & $44,000 \mathrm{~km}$ & 9,601 (39\%) \\
\hline
\end{tabular}

Note: Percentage of mean annual riverine TP from lowa (24,842 Mg). and discharge data and load estimation models to report annual TP export and yields in Iowa. In this study, TP concentrations were measured at an approximately monthly frequency at 46 ambient river monitoring sites across Iowa, with watershed sizes ranging from 88 to $20,155 \mathrm{~km}^{2}$. Although monthly measurements are not ideal to characterize TP concentrations, this sampling frequency was established by the Iowa Department of Natural Resources (IDNR) for their ambient river monitoring program. The ambient monitoring sites were specifically located to be beyond the extent of urban areas when the statewide ambient program was established. The sample size ranged from approximately 180 to nearly 220 for the 18 years between 2000 and 2017. Schilling et al. (2020) used two different US Geological Survey (USGS) software programs (Load Estimator [LOADEST] and Weighted Regressions on Time, Discharge and Season [WRTDS]) to estimate daily TP loads at the 46 monitoring sites. The daily load estimation captured TP loads associated with storm events. In the paper, results from the WRTDS methodology were summarized as annual TP loads and yields exported from Iowa watersheds (Schilling et al. 2020).

Mean (0.44 to $\left.7.71 \mathrm{~kg} \mathrm{ha}^{-1}\right)$ and median (0.32 to $3.75 \mathrm{~kg} \mathrm{ha}^{-1}$ ) annual TP yields were found to vary considerably across Iowa (Schilling et al. 2020). Highest median TP yields were found in hilly western and southern Iowa, with annual yields from many watersheds exceeding 2 to $3 \mathrm{~kg} \mathrm{ha}^{-1}$. In the flatter and more recently glaciated regions of north-central Iowa, median TP yields were often less than $1 \mathrm{~kg} \mathrm{ha}^{-1}$. In this study, we summarized TP export yields for 16 Iowa basins that directly discharge to the
Mississippi and Missouri rivers (figure 6). Based on area weighting the watershed-scale TP yields, we estimated that total TP export ranged from 5,377 to $72,182 \mathrm{Mg}$ and averaged 24,842 Mg (Schilling et al. 2020). This corresponds to a TP yield of $1.70 \mathrm{~kg} \mathrm{ha}^{-1}$ (median $1.40 \mathrm{~kg} \mathrm{ha}^{-1}$ ), ranging from 0.37 to $4.95 \mathrm{~kg} \mathrm{ha}^{-1}$ (table 3).

What Is the Contribution of Streambanks to Riverine Total Phosphorus Export? Using equations 1 and 2, we estimate that on a long-term annual basis, streambanks contribute approximately $31 \%$ of the riverine TP export from Iowa $(7,681 \mathrm{Mg}$ of streambank
$\mathrm{TP} / 24,842 \mathrm{Mg}$ of TP export). It is important to note that this represents a long-term average because annual riverine TP export from Iowa varies considerably (table 3 ). If we assume a constant streambank contribution of $7,681 \mathrm{Mg}$ and apply this to the range of annual TP export, the annual streambank contribution would vary considerably, ranging from $11 \%$ to $143 \%$.

Estimated annual streambank TP loss could vary based on a range of possible low or high estimates assumed for annual streambank recession, average TP concentrations, and eroding streambank lengths (table 2). For example, streambank TP contributions to Iowa export could range from $6 \%$ to $56 \%$ assuming low and high streambank recession rates ( \pm 1 s.d.). Similarly, if TP concentrations varied by \pm 1 s.d., and the annual TP export remained at $24,842 \mathrm{Mg}$, streambank contribution could conceivably range from $18 \%$ to $44 \%$. Finally, variability in eroding streambank lengths along Iowa rivers could contribute to variations in the fraction of P lost from streambanks. Assuming $\pm 10 \%$ or $\pm 25 \%$ difference in eroding streambank lengths would result in streambanks contributing approximately $28 \%$ to $34 \%$ and $23 \%$ to $39 \%$ of TP export, respectively. However,

\section{Figure 6}

Mean annual total phosphorus (TP) yields exported from 16 watersheds draining to the Mississippi and Missouri rivers (modified from Schilling et al. 2020).

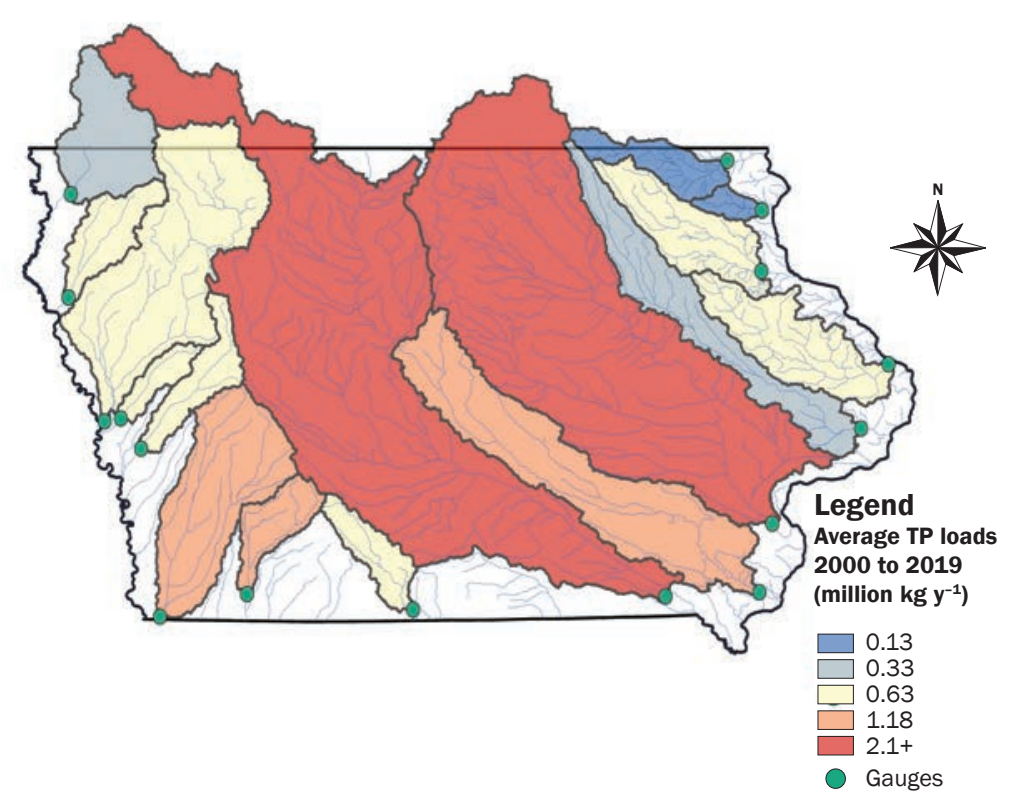




\section{Table 3}

Annual riverine export of total phosphorus (TP) in lowa and the estimated annual contribution from streambanks. Note that the annual streambank export is a constant (from equation 1).

\begin{tabular}{llclc}
\hline Year & $\begin{array}{l}\text { lowa mean TP } \\
\text { yield (kg ha }\end{array}$ & $\begin{array}{l}\text { lowa TP } \\
\text { load (Mg) }\end{array}$ & $\begin{array}{l}\text { Estimated annual TP } \\
\text { from streambanks }\end{array}$ & $\begin{array}{l}\text { Fraction of } \\
\text { lowa TP load from } \\
\text { streambanks (\%) }\end{array}$ \\
\hline 2000 & 0.49 & 7,128 & 7,681 & 108 \\
2001 & 2.11 & 30,701 & 7,681 & 25 \\
2002 & 0.63 & 9,232 & 7,681 & 83 \\
2003 & 0.74 & 10,744 & 7,681 & 71 \\
2004 & 1.99 & 29,065 & 7,681 & 26 \\
2005 & 0.68 & 9,936 & 7,681 & 77 \\
2006 & 0.52 & 7,576 & 7,681 & 101 \\
2007 & 3.51 & 51,211 & 7,681 & 15 \\
2008 & 4.95 & 72,182 & 7,681 & 11 \\
2009 & 1.33 & 19,415 & 7,681 & 40 \\
2010 & 3.49 & 50,929 & 7,681 & 15 \\
2011 & 1.30 & 19,015 & 7,681 & 40 \\
2012 & 0.37 & 5,377 & 7,681 & 143 \\
2013 & 1.47 & 21,368 & 7,681 & 36 \\
2014 & 2.12 & 30,900 & 7,681 & 25 \\
2015 & 1.88 & 27,354 & 7,681 & 28 \\
2016 & 1.89 & 27,573 & 7,681 & 28 \\
2017 & 1.20 & 17,444 & 7,681 & 31 \\
\hline Mean & 1.70 & 24,842 & 7,681 & \\
& & & & \\
\hline
\end{tabular}

the sensitivity results suggest that the longterm average contribution of streambank $\mathrm{TP}$ to river export (31\%) reported in this study represents a reasonable approximation for annual streambank TP contributions from third- to sixth-order streams in Iowa. The average contribution is consistent with the range of annual values reported in the literature for many watersheds, including estimates by Beck et al. (2018) for a single southern Iowa watershed (3\% to $38 \%$ ).

Study Limitations and Future Work. We acknowledge several key limitations in our estimation of the contribution of streambanks to statewide P export. First, while our GIS analysis routines were novel, the statewide eroding length model we developed was based on LiDAR elevation data collected from 2007 to 2010 . Hence, the elevation data used in this study are about a decade old and may not represent current conditions. For example, eroding streambanks can stabilize, or in other cases, new bank erosion can emerge due to channel migration or other factors (Palmer et al. 2014). Our results are appropriate at the regional scale of Iowa but should not be used for site-specific classification. For site-specific river assessments, actual field mapping of eroding streambanks would be needed (Tufekcioglu et al. 2012;
Beck et al. 2018; Peacher et al. 2018). It is anticipated that future regional-scale quantification of eroding banks will be possible in Iowa with sequential LiDAR flights that will allow DEMs from two time periods to be compared.

In addition, we were not able to quantify eroding lengths in first- and second-order channels. Smaller channels are vastly more numerous in watersheds than higher-order streams and rivers (Leopold et al. 1964; Schilling and Jacobson 2018). However, LiDAR resolution was not sufficient for delineating bank heights or widths with needed accuracy to estimate eroding lengths in these small channels. Along with unknown contributions from gully erosion, the additive $\mathrm{P}$ contributions from streambanks of small channels would serve to increase the estimated contribution of $\mathrm{P}$ from in-channel sources above the $31 \%$ suggested by this study. Hence, the $31 \%$ value reported herein is, in all likelihood, a conservative estimate of the contribution from Iowa streambanks. The TP export loads from Iowa reported by Schilling et al. (2020) include all of these known and unknown TP contributions.

Defining the interaction between bank recession, channel storage, and riverine sediment/P export is complex, especially in hydrologically altered landscapes. An additional challenge is estimating the potential pool and turnover of stored material represented in channel storage of sediment and $\mathrm{P}$ from streambank erosion. One important assumption in our study is that $\mathrm{P}$ associated with streambank recession is annually exported from the watershed when estimated over a long-term annual time frame. This assumption is supported by several regional studies. In one study, Beck (2018) estimated that total channel sediment storage in a stretch of third-order stream greatly exceeded watershed suspended sediment load in a dry year. However, the vast majority $(90 \%)$ of total storage mass was represented by colluvial material accumulations at the streambank toe and loose bed sediment, both easily transported during periods of higher discharge. Only a small percentage of stored $\mathrm{P}$ was associated with feature classes that would represent long-term storage (e.g., point bars). Additionally, the estimated volume of storage per meter of channel was found to be strikingly similar in this survey to one conducted in the same stream reach 17 years earlier (Schilling and Wolter 2000). The observed no net change in channel storage supports our assumption and may be a result of downcutting and widening channel evolution stages that dominate the region. However, the quantification of sediment and TP storage is exceptionally rare in the Midwest, especially in watersheds undergoing geomorphic adjustment in response to historic landscape-scale disturbances, and we recommend additional study of this topic.

Lastly, we note that there are many processes that drive severe streambank erosion in watersheds and acknowledge that simply accounting for severe bank erosion does not shed light on potential causal factors. Streambank erosion typically involves a variety of erosion processes, including fluvial erosion, mass wasting, and subaerial processes (Fox et al. 2016). Additional work will be needed to correlate study results to site-specific processes to shed light on the relation of severe bank erosion at a local scale to watershed-scale processes.

Implications for State Nutrient Reduction Strategies. To facilitate progress toward nutrient loading reduction goals articulated in the Gulf Hypoxia Action Plan (2008), states within the Mississippi River basin have been developing nutrient loss reduction strategies (Christianson et al. 2018). Inherent in 
any strategy is the need to estimate nutrient loads over some time period (baseline) and evaluate potential load reductions resulting from implementation of conservation practices associated with strategy goals. While states have employed various approaches to estimate nutrient loads from point and nonpoint sources, one consistent limitation has been an estimate of the nutrient load contribution from stream bed and bank erosion. In the case of the Iowa Nutrient Reduction Strategy (2017), the authors stated that

Streambanks are known to be a potentially large source of stream sediment.... However, accurately accounting for streambank sources of $\mathrm{P}$ is extremely difficult and methods have not been developed to quantify streambank sediment contributions beyond a local scale. Therefore, evaluating strategies to reduce $\mathrm{P}$ losses from point sources and eroding streambanks (i.e., runoff volume reduction or bank stabilization) are beyond the scope of this effort.

Our study describes the first estimate of the contribution of streambank sources to statewide TP export within a state within the Mississippi River basin in order to inform Iowa's Nutrient Reduction Strategy.

Herein we estimated the annual streambank contribution of TP from third- to sixth-order streams to statewide TP export from Iowa to be approximately $31 \%$. While there are acknowledged limitations to estimates at this scale, along with significant annual variability, it is apparent that streambank erosion comprises a significant source of TP export from the state of Iowa and the contribution needs to be addressed along with more recognized nutrient sources if we are to achieve reduction strategy goals. However, nearly all conservation practices identified within nutrient reduction strategies are designed to reduce in-field sources of $\mathrm{P}$ via a reduction in soil erosion. By some estimates, historic investment in these practices has substantially reduced soil erosion (and P flux) to surface waters (Jones and Schilling 2011), but such reductions may not be translated into equivalent $\mathrm{P}$ reductions when measured at the watershed scale. Our results point out the critical need to develop and implement conservation practices that address both upland erosion (and P loss) and in-stream sources to help mitigate the downstream impacts on water quality.

Upland sediment erosion and the implementation of location-appropriate conservation practices have long been the focus for conservationists and most are well recognized and understood. In fact, there is growing evidence that we may be reaching a point of diminishing returns for locating conservation practices that focus on reducing sediment $\mathrm{P}$ loss from upland sheet and rill erosion (Rundhaug et al. 2018; Streeter et al. 2021). However, in-stream sediment dynamics remain a significant challenge because they are inherently complex and driven by watershed-scale processes. Sediment (and P) transport in rivers and streams is determined by a dynamic equilibrium among discharge, slope, sediment load, and sediment size (Lane 1955). In watersheds dominated by agriculture such as those in the upper Mississippi River basin, shifts in equilibrium have been attributed to historic land use change (Knox 2001), artificial drainage (Schottler et al. 2014), and channelization (Landmaine et al. 2015). In addition to these alterations, increases in streambank erosion have been compounded by historic increases in precipitation (Qian et al. 2007) that are predicted to continue in the future (Villarini et al. 2013; Takle and Gutowski 2020). These alterations and shifts in climate have resulted in morphologically novel stream configurations exhibiting multiple channel evolution stages (Simon and Rinaldi 2006). Due to this complexity, unlike more traditional upland conservation practices, there is little research on effective and economical practices to reduce streambank erosion at the watershed scale (Fox et al. 2016). Additional research is needed to understand the intricate linkage between upland practices and instream response as loss of streambank $\mathrm{P}$ will continue to contribute to $\mathrm{P}$ export as long as the hydrology and geomorphology of Iowa rivers and streams are out of equilibrium.

Lastly, while it is important to recognize the potentially significant contribution of streambank erosion to $\mathrm{P}$ export from agricultural watersheds, addressing the issue will be a tremendous challenge. Best management practices for streambank protection tend to be constructed to protect individual banks, and there is a need to clarify the benefits of these small-scale restorations or stabilizations on total watershed sediment (and P) load (Nellesen et al. 2011). Improved understanding of the location and timing of streambank erosion within a watershed context is needed (Fox et al. 2016; Palmer et al. 2014), and it will be important to evaluate the interactions of streambank mitigation actions on hydrological and erosion processes at both a reach and watershed scale. An improved understanding of the erosion and transport of sediment and $\mathrm{P}$ from both upland and channel sources will help natural resource managers make improved recommendations for installing effective soil and water conservation practices at the appropriate location and scale to achieve cost-effective nutrient reduction.

\section{Summary and Conclusions}

The contribution of streambank sources to TP export from the state of Iowa was estimated using a multistep process. A combination of field mapping and GIS analysis was used to estimate that $35,200 \mathrm{~m}$ of 3.2 $\mathrm{m}$ high streambanks are actively eroding in Iowa rivers at a rate of $12.4 \mathrm{~cm} \mathrm{y}^{-1}$. Field sampling of exposed streambanks across various regions of Iowa indicated that streambank soils had mean TP concentration of $470 \mathrm{mg}$ $\mathrm{kg}^{-1}$ and bulk density of $1.17 \mathrm{~g} \mathrm{~cm}^{-3}$. Based on these data, we estimated that approximately 7,681 $\mathrm{Mg}$ of TP is annually eroded from streambanks and delivered to Iowa rivers. Comparing this streambank export to total TP export from the state (Schilling et al. 2020 ), over an 18-year period, we estimated that streambanks contributed approximately $31 \%$ of the riverine TP export from Iowa. Despite limitations in our analysis, an improved understanding of streambank $\mathrm{P}$ contributions will help natural resource managers make appropriate recommendations for effective soil and water conservation practices that best reduce $\mathrm{P}$ loading to rivers.

\section{Acknowledgements}

Funding for the project was provided, in part, by the Iowa Nutrient Research Center under grant INRC 2017-01 and the Iowa Department of Transportation Project RB10-014 Bank Stability Assessment Tool.

\section{References}

Beck, W.J. 2018. Sediment and phosphorus dynamics within the channel and floodplain of Walnut Creek, Iowa. PhD dissertation, Iowa State University.

Beck, W., T. Isenhart, P. Moore, K. Schilling, R. Schultz, and M. Tomer. 2018. Streambank alluvial unit contributions to suspended sediment and total phosphorus loads, Walnut Creek, Iowa, USA. Water 10:111. 
Beck, W.J., P.L. Moore, K.E. Schilling, C.F. Wolter, T.M. Isenhart, K.J. Cole, and M.D. Tomer. 2019. Changes in lateral floodplain connectivity accompanying stream channel evolution: Implications for sediment and nutrient budgets. Science of the Total Environment 660:1015-1028.

Belmont, P., K.B. Gran, S.P. Schottler, P.R. Wilcock, S.S. Day, C. Jennings, J.W. Lauer, E. Viparelli, J.K. Willenbring, D.R. Engstrom, and G. Parker. 2011. Large shift in source of fine sediment in the Upper Mississippi River. Environmental Science \& Technology 45:8804-8810.

Christianson, R., L. Christianson, C. Wong, M. Helmers, G. McIsaac, D. Mulla, and M. McDonald. 2018. Beyond the nutrient strategies: Common ground to accelerate agricultural water quality improvement in the upper Midwest. Journal of Environmental Management 206:1072-1080.

Couper, P., T. Stott, and I. Maddock. 2002. Insights into river bank erosion processes derived from analysis of negative erosion-pin recordings: Observations from three recent UK studies. Earth Surface Processes and Landforms 27:59-79.

Crosland, A.R., F.J, Zhao, S.P. McGrath, and P.W. Lane. 1995. Comparison of aqua regia digestion with sodium carbonate fusion for the determination of total phosphorus in soils by inductively coupled plasma atomic emission spectroscopy (ICP). Communications in Soil Science and Plant Analysis 26:1357-1368.

Diaz, R.J. 2001. Overview of hypoxia around the world. Journal of Environmental Quality 30:275-281.

Florsheim, J.L., J.F. Mount, and A. Chin. 2008. Bank erosion as a desirable attribute of rivers. BioScience 58:519-529.

Fox, G.A., R.A. Purvis, and C.J. Penn. 2016. Streambanks: A net source of sediment and phosphorus to streams and rivers. Journal of Environmental Management 181:602-614.

Fox, G.A., G.V.Wilson, A. Simon, E.J. Langendoen, O. Akay, and J.W. Fuchs. 2007. Measuring streambank erosion due to ground water seepage: Correlation to bank pore water pressure, precipitation and stream stage. Earth Surface Processes and Landforms 32:1558-1573.

Gentry, L.E., M.B. David, T.V. Royer, C.A. Mitchell, and K.M. Starks. 2007. Phosphorus transport pathways to streams in tile-drained agricultural watersheds. Journal of Environmental Quality 36:408-415.

Hamlett, J.M., J.L. Baker, and H.P. Johnson. 1983. Channel morphology changes and sediment yield for a small agricultural watershed in Iowa. Transactions of the ASAE 26:1390-1396.

Hecky, R.E., and P. Kilham. 1988. Nutrient limitation of phytoplankton in freshwater and marine environments: A review of recent evidence on the effects of enrichment. Limnology and Oceanography 33:796-822.

Hooke, J.M. 1980. Magnitude and distribution of rates of river bank erosion. Earth surface Processes 5:143-157.

Ishee, E.R., D.S. Ross, K.M. Garvey, R.R. Bourgault, and C.R. Ford. 2015. Phosphorus characterization and contribution from eroding streambank soils of Vermont's Lake Champlain Basin. Journal of Environmental Quality 44:1745-1753.

Jacobson, L.M., M.B. David, and L.E. Drinkwater. 2011. A spatial analysis of phosphorus in the Mississippi River Basin. Journal of Environmental Quality 40:931-941.

Jones, C.S., J.K. Nielsen, K.E. Schilling, and L.J. Weber. 2018 Iowa stream nitrate and the Gulf of Mexico. PloS One 13:e0195930

Jones, C.S., and K.E. Schilling. 2011. From agricultural intensification to conservation: Sediment transport in the Raccoon River, Iowa, 1916-2009. Journal of Environmental Quality 40:1911-1923.

King, K.W., M.R. Williams, and N.R. Fausey. 2015a Contributions of systematic tile drainage to watershedscale phosphorus transport. Journal of Environmental Quality 44:486-494.

King, K.W., M.R. Williams, M.L. Macrae, N.R. Fausey, J. Frankenberger, D.R. Smith, P.J. Kleinman, and L.C. Brown. 2015b. Phosphorus transport in agricultural subsurface drainage: A review. Journal of Environmental Quality 44:467-485.

Knox, J.C. 2001. Agricultural influence on landscape sensitivity in the Upper Mississippi River Valley. Catena 42:193-224.

Kronvang, B., J.Audet, A. Baattrup-Pedersen, H.S. Jensen, and S.E. Larsen. 2012. Phosphorus load to surface water from bank erosion in a Danish lowland river basin. Journal of Environmental Quality 41:304-313.

Landemaine, V., A. Gay, O. Cerdan, S. Salvador-Blanes, and S. Rodrigues. 2015. Morphological evolution of a rural headwater stream after channelization. Geomorphology 230:125-137.

Lane, E.W. 1955. Importance of fluvial morphology in hydraulic engineering. Proceedings of the American Society of Civil Engineers 81(7):1-17.

Laubel, A., K.B. Kronvang, A.B. Hald, and C. Jensen. 2003 Hydromorphological and biological factors influencing sediment and phosphorus loss via bank erosion in small lowland rural streams in Denmark. Hydrological Processes 17:3443-3463.

Lawler, D.M. 1992. Process dominance in bank erosion systems. In Lowland Floodplain Rivers: Geomorphological Perspectives, ed. P.A. Carling and G.E. Petts, 117-143. Chichester, UK: Wiley.

Leopold, L.B., M.G. Wolman, and J.P. Miller. 1964. Fluvial Processes in Geomorphology. San Francisco, CA: Freeman.

Miller, R.B., G.A. Fox, C.J. Penn, S. Wilson, A. Parnell, R.A. Purvis, and K. Criswell. 2014. Estimating sediment and phosphorus loads from streambanks with and without riparian protection. Agriculture, Ecosystems \& Environment 189:70-81

Moustakidis, I.V., K.E. Schilling, and L.J. Weber. 2019. Soil total phosphorus deposition and variability patterns across the floodplains of an Iowa river. Catena 174:84-94.
Nellesen, S.L., J.L. Kovar, M.M. Haan, and J.R. Russell. 2011 Grazing management effects on stream bank erosion and phosphorus delivery to a pasture stream. Canadian Journal of Soil Science 91:385-395.

Palmer, J.A., K.E. Schilling, T.M. Isenhart, R.C. Schultz, and M.D. Tomer. 2014. Streambank erosion rates and loads within a single watershed: Bridging the gap between temporal and spatial scales. Geomorphology 209:66-78.

Peacher, R.D., R.N. Lerch, R.C. Schultz, C.D. Willett, and T.M. Isenhart. 2018. Factors controlling streambank erosion and phosphorus loss in claypan watersheds. Journal of Soil and Water Conservation 73(2):189-199. https://doi.org/10.2489/jswc.73.2.189.

Piégay, H., S.E. Darby, E. Mosselman, and N. Surian. 2005. A review of techniques available for delimiting the erodible river corridor: A sustainable approach to managing bank erosion. River Research and Applications 21:773-789.

Pollen, N., A. Simon, and A. Collison. 2004. Advances in assessing the mechanical and hydrologic effects of riparian vegetation on streambank stability. Riparian Vegetation and Fluvial Geomorphology 8:125-139.

Purvis, R.A., and G.A. Fox. 2016. Streambank sediment loading rates at the watershed scale and the benefit of riparian protection. Earth Surface Processes and Landforms 41:1327-1336.

Qian, T., A. Dai, and K.E. Trenberth. 2007. Hydroclimatic trends in the Mississippi River basin from 1948 to 2004. Journal of Climate 20:4599-4614.

Rahutomo, S., J.L. Kovar, and M.L. Thompson. 2018 Inorganic and organic phosphorus in sediments in the Walnut Creek Watershed of central Iowa, USA. Water, Air, \& Soil Pollution 229:1-12.

Rundhaug, T.J., G.R. Geimer, C.W. Drake, A.A.Amado, A.A. Bradley, C.F. Wolter, and L.J. Weber. 2018. Agricultural conservation practices in Iowa watersheds: Comparing actual implementation with practice potential. Environmental Monitoring and Assessment 190:659.

Robertson, D.M., and S.A. Saad. 2013. SPARROW models used to understand nutrient sources in the Mississippi/ Atchafalaya River Basin. Journal of Environmental Quality 42:1422-1440

Schilling, K.E., T.M. Isenhart, J.A. Palmer, C.F. Wolter, and J. Spooner. 2011. Impacts of land-cover change on suspended sediment transport in two agricultural watersheds. Journal of the American Water Resources Association 47:672-686.

Schilling, K.E., P.J. Jacobson, and C.F. Wolter. 2018. Using riparian zone scaling to optimize buffer placement and effectiveness. Landscape Ecology 33:141-156.

Schilling, K.E., S.W. Kim, C.S. Jones, and C.F. Wolter. 2017. Orthophosphorus contributions to total phosphorus concentrations and loads in Iowa agricultural watersheds. Journal of Environmental Quality 46:828-835.

Schilling, K.E., J.A. Palmer, E.A. Bettis III, P. Jacobson, R.C. Schultz, and T.M. Isenhart. 2009. Vertical distribution of total carbon, nitrogen and phosphorus in riparian soils of Walnut Creek, southern Iowa. Catena 77:266-273. 
Schilling, K.E., M.T. Streeter, A. Seeman, C.S. Jones, and C.F. Wolter. 2020. Total phosphorus export from Iowa agricultural watersheds: Quantifying the scope and scale of a regional condition. Journal of Hydrology 581:124397.

Schilling, K.E., and C.F. Wolter. 2000. Application of GPS and GIS to map channel features in Walnut Creek, Iowa. Journal of the American Water Resources Association 36:1423-1434.

Schottler, S.P., J. Ulrich, P. Belmont, R. Moore, J.W. Lauer, D.R. Engstrom, and J.E. Almendinger. 2014. Twentieth century agricultural drainage creates more erosive rivers. Hydrological Processes 28:1951-1961.

Sekely, A.C., D.J. Mulla, and D.W. Bauer. 2002. Streambank slumping and its contribution to the phosphorus and suspended sediment loads of the Blue Earth River, Minnesota. Journal of Soil and Water Conservation 57(5):243-250.

Sharpley, A. 1995. Identifying sites vulnerable to phosphorus loss in agricultural runoff. Journal of Environmental Quality 24:947-951.

Simon, A., and A.J. Collison. 2002. Quantifying the mechanical and hydrologic effects of riparian vegetation on streambank stability. Earth Surface Processes and Landforms 27:527-546.

Simon, A., A. Curini, S. Darby, and E.J. Langendoen. 2000. Bank and near-bank processes in an incised channel. Geomorphology 35:193-217.

Simon, A., and M. Rinaldi. 2000. Channel instability in the loess area of the Midwestern United States. Journal of the American Water Resources Association 36:133-150.

Simon, A., and M. Rinaldi. 2006. Disturbance, stream incision, and channel evolution: The roles of excess transport capacity and boundary materials in controlling channel response. Geomorphology 79:361-383.

Smith, D.R., K.W. King, L. Johnson, W. Francesconi, P. Richards, D. Baker, and A.N. Sharpley. 2015. Surface runoff and tile drainage transport of phosphorus in the midwestern United States. Journal of Environmental Quality 44:495-502.

Stamm, C.H., H. Flühler, R. Gächter, J. Leuenberger, and H. Wunderli. 1998. Preferential transport of phosphorus in drained grassland soils. Journal of Environmental Quality 27:515-522.

Streeter, M.T., K.E. Schilling, C.L. Burras, and C.F. Wolter. 2021. Erosion and sediment delivery in southern Iowa watersheds: Implications for conservation planning. Journal of Soil and Water Conservation 76(2):103-115. https://doi.org/10.2489/jswc.2021.00125.

Sylvan, J.B., Q. Dortch, D.M. Nelson, A.F. Maier Brown, W. Morrison, and J.W.Ammerman. 2006. Phosphorus limits phytoplankton growth on the Louisiana shelf during the period of hypoxia formation. Environmental Science \& Technology 40:7548-7553.

Takle, E.S., and W.J. Gutowski Jr. 2020. Iowa's agriculture is losing its Goldilocks climate. Physics Today 73:26-33.
Thoma, D.P., S.C. Gupta, M.E. Bauer, and C.E. Kirchoff. 2005. Airborne laser scanning for riverbank erosion assessment. Remote Sensing of Environment 95:493-501.

Tomer, M.D., and J.D. Van Horn. 2018. Stream bank and sediment movement associated with 2008 flooding, South Fork Iowa River. Journal of Soil and Water Conservation 73(2):97-106. https://doi.org/10.2489/ jswc.73.2.97.

Tufekcioglu, M., T.M. Isenhart, R.C. Schultz, D.A. Bear, J.L. Kovar, and J.R. Russell. 2012. Stream bank erosion as a source of sediment and phosphorus in grazed pastures of the Rathbun Lake Watershed in southern Iowa, United States. Journal of Soil and Water Conservation 67(6):545-555. https://doi.org/10.2489/jswc.67.6.545.

Turner, R.E., N.N. Rabalais, and D. Justic. 2008. Gulf of Mexico hypoxia: Alternate states and a legacy. Environmental Science \& Technology 42:2323-2327.

USDA NRCS (Natural Resources Conservation Service). 1998. Erosion and Sediment Delivery. Field Office Technical Guide Notice No. IA-198. Des Moines, IA: USDA Natural Resources Conservation Service.

Villarini, G., E. Scoccimarro, and S. Gualdi. 2013. Projections of heavy rainfall over the central United States based on CMIP5 models. Atmospheric Science Letters 14:200-205

Watanabe, F.S., and S.R. Olsen. 1965. Test of an ascorbic acid method for determining phosphorus in water and $\mathrm{NaHCO}_{3}$ extracts from soil. Soil Science Society of America, Proceedings 29:677-678.

Willett, C.D., R.N. Lerch, R.C. Schultz, S.A. Berges, P.D. Peacher, and T.M. Isenhart. 2012. Streambank erosion in two watersheds of the Central Claypan Region of Missouri, United States. Journal of Soil and Water Conservation 67(4):249-263. https://doi.org/10.2489/ jswc.67.4.249.

Wilkin, D.C., and S.J. Hebel. 1982. Erosion, redeposition, and delivery of sediment to Midwestern streams. Water Resources Research 18:1278-1282.

Williams, F. 2019. Combining field and automated methods to estimate bank erosion: A regional estimation of sediment and phosphorus loads. Unpublished Master's thesis, Iowa State University.

Wilson, C.G., R.A. Kuhnle, D.D. Bosch, J.L. Steiner, P. Starks, M.D.Tomer, and G.V.Wilson. 2008. Quantifying relative contributions from sediment sources in Conservation Effects Assessment Project watersheds. Journal of Soil and Water Conservation 63(6):523-532. https://doi. org/10.2489/jswc.63.6.523.

Wolter, C.F., K.E. Schilling, and J.A. Palmer. 2021. Quantifying the extent of eroding streambanks in Iowa. Journal of the American Water Resources Association 57:391-405.

Zaimes, G.N., R.C. Schultz, and T.M. Isenhart. 2004. Stream bank erosion adjacent to riparian forest buffers, rowcrop fields, and continuously-grazed pastures along
Bear Creek in central Iowa. Journal of Soil and Water Conservation 59(1):19-27.

Zaimes, G.N., R.C. Schultz, and T.M. Isenhart. 2006. Riparian land uses and precipitation influences on stream erosion in central Iowa. Journal of the American Water Resources Association 42:83-97.

Zaimes, G.N., R.C. Schultz, and T.M. Isenhart. 2008. Streambank soil and phosphorus losses under different riparian land-uses in Iowa. Journal of the American Water Resources Association 44:935-947.

Zaimes, G.N., M. Tufekcioglu, and R.C. Schultz. 2019. Riparian land-use impacts on stream bank and gully erosion in agricultural watersheds: What we have learned. Water 11:1343. 